\title{
Test de Français Laval-Montreal: Does It Measure What It Should Measure?
}

\section{Romain Schmitt E Shahrzad Saif}

This article reports on a study conducted as part of a larger investigation of the predictive validity of the Test de Français Laval-Montreal (TFLM), a high-stakes French language test used for admission and placement purposes for TeacherTraining Programs (TTPS) in major francophone universities in Canada (Schmitt, 2015). The objective of this study is to examine the validity of TFLM tasks for measuring language abilities required by tasks common to the Target Language Use (TLU; Bachman \& Palmer, 2010) domains in which preservice teachers are expected to function. Adopting Messick's conception of construct validity (1989) and Bachman E Palmer's Framework of Task Characteristics (2010), the study features a comprehensive task analysis detailing the characteristics of TFLM tasks in contrast to those of three major TLU academic and instructional contexts linked to the test. The results of the study are discussed in terms of the standards of validity (Messick, 1996) and qualities of usefulness (Bachman E Palmer, 1996). Findings suggest that TFLM tasks and constructs do not represent those of the TLU contexts and do not address the language needs of preservice teachers as identified by the Ministère de l'Éducation, du Loisir et du Sport (MELS). The implications for the consequential aspect of TFLM validity and the potential negative consequences of TFLM use as an admission test are discussed.

Cet article présente une partie d'une étude plus complète sur la validité prédictive du Test de Français Laval-Montréal (TFLM), test de langue française à enjeux critiques utilisé comme test d'admission et de placement dans les programmes de formation initiale en enseignement d'importantes universités francophones au Canada (Schmitt, 2015). Le but de cette étude est d'analyser la validité des tâches du TFLM à des fins d'évaluation des compétences linguistiques exigées dans les tâches communes aux domaines d'utilisation de la langue cible dans lesquels les enseignants en formation doivent fonctionner (Target Language Use (TLU); Bachman E Palmer, 2010). Basée sur la conception de la validité conceptuelle de Messick (1989) et le cadre d'analyse des caractéristiques des tâches de Bachman $\mathcal{E}$ Palmer (2010), l'étude compare de manière détaillée les tâches du TFLM à celles de trois contextes académiques et pédagogiques d'emploi de la langue cible. Les résultats de cette analyse sont évalués en termes de validité (Messick, 1996) et des qualités des tests (Bachman E Palmer, 1996). Les résultats indiquent que les tâches du TFLM et les construits qu'il est sensé évaluer ne correspondent pas à ceux des contextes d'emploi de la langue cible et ne répondent pas aux besoins des enseignants en formation tels qu'identifiés par le Ministère de l'Éducation, du Loisir et du Sport (MELS). La validité du TFLM, les conséquences ainsi que les aspects potentiellement négatifs de son utilisation comme test d'admission sont discutés. 


\section{Background to the Study}

This study examines the task characteristics of a high-stakes French language test whose score is used as an admission requirement to the teacher training programs (TTPs) in francophone universities in the province of Quebec. Previous studies examining the predictive validity of admission tests have mainly focused on standardized English language tests as measures of L2 proficiency (Elder, 1993; Morris \& Cobb, 2004). Few have investigated the validity of admission tests measuring candidates' L1 (Blais, 2001; Romainville, 1997), and none, to our knowledge, has investigated a French language test as a measure of L1 proficiency in Quebec, the sole officially unilingual French province in Canada and the stronghold of the French language in North America.

The status of the French language in Quebec as well as Quebecers' perception of French is rooted in history, the language being part of Quebec identity. It is therefore not surprising that measures have been taken by successive governments of all allegiances to highlight and protect this linguistic identity of Quebec. In 1977, for example, Quebec legislators passed into law Bill 101, the Charter of the French Language, in an attempt to ensure that French remains the language of the majority and continues to grow in Quebec. Bill 101 legally restricts access to English school boards, requires immigrants to be schooled in French, and mandates businesses to offer services primarily in French. Although disputed and polemical, Bill 101 is considered to be the cornerstone of Quebec language policy and is revered by most as a piece of legislation that preserves the French language from the overwhelming dominance of English spoken in the rest of Canada.

The preoccupation with the quality of the French language is therefore paramount at all levels in the Quebec educational system. Teachers, in particular, are expected to act as linguistic models for their students and to possess a comprehensive command of French, both linguistically and culturally. This priority was underlined in 2001 during the États Généraux de la langue française au Québec, a province-wide symposium whose purpose was to identify issues with the quality of French in Quebec and find possible ways to improve it in all layers of society and for all users. The result was a comprehensive and lengthy report (commonly named the Larose Report, after the commissioner who presided over the symposium) identifying the issues and suggesting elements of response (Commission des états généraux sur l'avenir de la langue française au Québec, 2001). One particular issue addressed in the report was the quality of French among teachers identified in response to a request by the Association Québécoise des Professeures et professeurs de Français (AQPF, 2001; Association of Quebec French Teachers) demanding that the government set minimal requirements for French, both linguistically and culturally, for the admission of candidates into TTPs in Quebec universities. This demand coincided with a referential document (Ministère de l'Éducation, 
du Loisir et du Sport [MELS], 2001) that elaborated the requirements for the teaching profession in the form of 12 professional competencies (PCs), two of which specifically address the issues raised by the AQPF: the cultural knowledge (PC1) and the linguistic competency (PC2) expected from all preservice and inservice education professionals:

PC1: To act as a professional who is inheritor, critic, and interpreter of knowledge or culture when teaching students. (p. 57)

PC2: To communicate clearly in the language of instruction, both orally and in writing, using correct grammar, in various contexts related to teaching. (p. 63)

In addition, the practicums that were part of the TTPs' curriculum underwent a major reform in 2001, the implementation of which necessitated major financial commitments on the part of the universities offering these programs. The new practicum guidelines required extra training, hiring, sometimes creating whole departments/offices for the sole purpose of organizing placements, evaluating students' performance during their practicums, and setting up administrative and information technology (IT) platforms necessary for these activities.

These governmental orientations were, in large part, in response to a general and societal demand voiced by the popular media targeting teachers' poor language skills and calling for school teachers to be, first and foremost, the linguistic role models for Quebec youth (Commission des États généraux sur l'éducation, 1996; Gagnon, 2005; Gauvreau, 2003). This popular and media-led criticism highlighted the need for screening the candidates at the time of admission as a way of ensuring that the graduating teacher candidates entering the workplace would be qualified for teaching jobs. At the same time, for faculties faced with the financial burden of the government-imposed adjustments to the TTPs' curriculum, the need to select only the students most likely to succeed in their program increased dramatically. Quebec's two major francophone universities, Université Laval and Université de Montréal, therefore, embarked on the development of a screening device, Test de Français Laval Montréal (TFLM), as an admission requirement to all TTPs, including the English as a Second Language (ESL) teacher-training program for which the language of instruction is English. It is important to note that the applicants to TTPs in Quebec are overwhelmingly francophone, hence the status of TFLM as a measure of candidates' L1. TFLM scores are therefore highly consequential in Quebec's teacher-training domain. The question, however, remains as to whether TFLM tasks adequately measure the language abilities required for the successful completion of the language-related tasks in such real-life contexts as undergraduate TTPs or school contexts. In the following section, the content and the constructs measured by TFLM are introduced and discussed in some detail. 


\section{Test de Français Laval-Montreal: Tasks and Constructs}

TFLM is a paper-and-pencil test of linguistic code used as an admission requirement for many programs, including TTPs at Université Laval (Appendix A) and Université de Montréal (and its affiliates, such as École Polytechnique de Montréal). The test, administered in 90 minutes, is composed of 65 (Université Laval) or 66 (Université de Montréal) multiple-choice questions, divided into 5 sections: lexical spelling (4 items), grammar spelling (24 items), morphology (5 items), syntax (13 items), and vocabulary (19 items). Different sections of the TFLM, with sample items, are summarized in Table 1.

Table 1

TFLM Sections and Sample Questions at Université Laval, Quebec

\begin{tabular}{|c|c|c|}
\hline & Section & $\begin{array}{l}\text { Sample item } \\
\text { Instruction: Rayez l'énoncé incorrect }\end{array}$ \\
\hline \multirow{5}{*}{ 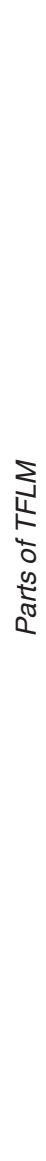 } & $\begin{array}{l}\text { Lexical spelling } \\
4 \text { items }\end{array}$ & $\begin{array}{l}\text { A : Je marche rapidement. } \\
\text { B : Le chien aboie méchament. } \\
\text { C : Mes parents m'encouragent allègrement. } \\
\text { D : Tu parles trop vite. } \\
\text { E : Tous les énoncés sont corrects. }\end{array}$ \\
\hline & $\begin{array}{l}\text { Grammar spelling } \\
24 \text { items }\end{array}$ & $\begin{array}{l}\text { A : Marie a envoyé des fleurs à sa mère. } \\
\mathrm{B}: \text { Les amis à qui Jean a parlés l'ont rappelé. } \\
\mathrm{C}: \text { Les amis à qui Marie a parlé l'ont rappelée. } \\
\mathrm{D}: \text { Mon chien a dévoré la perruche du voisin. } \\
\mathrm{E}: \text { Tous les énoncés sont corrects. }\end{array}$ \\
\hline & $\begin{array}{l}\text { Morphology (Genders, } \\
\text { singular-plural, conjugation) } \\
5 \text { items }\end{array}$ & $\begin{array}{l}\text { A : Le loup hurle à la lune. } \\
\text { B : Les amis de Jean lui envoyent des souhaits } \\
\text { chaque année. } \\
C: \text { Je regrette, mais cela ne sera pas possible. } \\
D: \text { Vous connaissez cette personne? } \\
\text { E : Tous les énoncés sont corrects. }\end{array}$ \\
\hline & $\begin{array}{l}\text { Syntax (use of auxiliary verbs, } \\
\text { modes and tenses, use of rela- } \\
\text { tive pronoun, structure of sen- } \\
\text { tences, negation, punctuation) } \\
13 \text { items }\end{array}$ & $\begin{array}{l}\text { A : Je suis monté à l'étage. } \\
B \text { : J'ai monté la télévision à l'étage. } \\
C \text { : J'ai descendu à la cave. } \\
\text { D : J'ai descendu les escaliers. } \\
\text { E : Tous les énoncés sont corrects. }\end{array}$ \\
\hline & $\begin{array}{l}\text { Vocabulary (Anglicism, use } \\
\text { of prepositions, conjunctions, } \\
\text { knowledge of lexicon) } \\
19 \text { items }\end{array}$ & $\begin{array}{l}\text { A : Le chanteur a un rhume ; cependant, il a annulé } \\
\text { son spectacle. } \\
\text { B : Le chanteur a un rhume ; il a malgré cela } \\
\text { annulé son spectacle. } \\
\text { C : Le chanteur a un rhume ; il a donc annulé son } \\
\text { spectacle. } \\
\text { D : Le chanteur a un rhume ; nonobstant, il a } \\
\text { annulé son spectacle. } \\
\text { E : Tous les énoncés sont corrects. }\end{array}$ \\
\hline
\end{tabular}


At Université de Montréal, the cut-off score is $60 \%$ for all programs, including TTPs, whereas at Université Laval, the context of this study, the passing score is $75 \%$ for all TTPs, with the exception of the Teaching English as a Second Language program, for which the passing score is $60 \%$. The cut-off scores seem to have been arbitrarily assigned by the two universities, as there is no systematic study justifying the differences. It is also worth mentioning that despite a lower passing score, Université de Montréal requires the students who do not score $60 \%$ to take fewer remedial French courses (i.e., one course) than Université Laval (see below). At Université Laval, the test score is used by the admission office to group incoming students into three proficiency groups: high-performing students (HIGH), whose TFLM score is above $75 \%$; average-performing students (MID), whose TFLM score is between 60 and 74\%; and low-performing students (LOW), whose TFLM score is below $60 \%$. Extra French courses are imposed on students placed in the MID (1 course) and the LOW ( 2 courses) groups. To ensure the successful completion of the program, the university requires the students to complete all remedial courses within the first two years following admission to TTPs. TFLM is therefore considered to be a high-stakes test, by the test-takers and the test users alike, as TTPs are the only compulsory path for anyone wanting to become a teacher in the province of Quebec.

As for the courses within the TTPs, they present two different dimensions: specialized courses that are specific to each program (such as science, history, French as a first or second language, etc.) and common didactic courses (social aspects of education, laws, ethical concerns, etc.) that focus on pedagogical aspects of the teaching profession. To these two dimensions is added the quality of language, which involves cultural knowledge and the fundamentals of the profession (MELS' 12 professional competencies, 2001). As a result, during their training program, preservice teachers have to perform a variety of language-related tasks in different academic and real-life settings, namely the content-specific and didactic courses, French language courses (to which they will be assigned based on their TFLM score), and practicums in public schools. A language admission test to TTPs should, therefore, reflect the complexity of tasks required by these various settings. To fully understand the validity of TFLM as a measure of candidates' linguistic ability for functioning in these target language use (TLU) contexts, this study will present an analysis of the test task characteristics in relation to those of the TLU contexts.

\section{The Problem}

As an admission and placement criterion for TTPs at major francophone universities in Quebec, the TFLM score is consequential to test-takers and score users alike. TFLM is the gatekeeper for TTPs, which constitute the only path to the teaching profession in the province of Quebec. At the same time, extra French language courses imposed on candidates with lower scores on TFLM are costly and could prolong their studies. As well, the lo- 
gistics of the test administration and the subsequent placement of students in remedial courses are costly and time-consuming for the universities. Given this high-stakes status of TFLM, it is of utmost importance to ensure that the test score is valid for the purposes to which it is put: admitting candidates that possess the language abilities fundamental to success in TTPs as well as real-life instructional contexts, and placing students in different remedial courses linked to the test. The validity of the TFLM score (or lack thereof) could have important positive or negative consequences for the candidates, for the teacher training programs, and, eventually, for Quebec education.

Despite claims to the contrary (see Appendix A), to our knowledge, TFLM has not to date been subject to a systematic validity study. The present study, as part of a larger investigation of the predictive validity of TFLM (Schmitt, 2015), explores the validity of TFLM tasks for measuring language abilities required by tasks common to the TLU (Bachman \& Palmer, 2010) domains in which preservice teachers are expected to function. The study addresses the following research questions (RQs):

1. What are the task characteristics of TFLM?

2. Is there a correspondence between TFLM tasks and those of the content courses (TLU1)?

3. Is there a correspondence between TFLM tasks and those of the remedial courses (TLU2) linked to it?

4. Is there a correspondence between TFLM tasks and those of the real-life teaching context (TLU3)?

\section{Conceptual Framework}

The testing instrument under investigation in this study and in our context, TFLM, is a high-stakes test of French language proficiency whose score is used for making important admission and placement decisions that are consequential to the test-takers and score users alike. In other words, the TFLM scores are not simply used as tools for descriptive purposes; they are used as a basis for further actions or decisions by francophone universities in Quebec. As a result, the suitability of the TFLM scores for admission and for making differential placement decisions crucially depends on how well it can predict the students' performance in the programs and future remedial courses linked to it. The relationship between the abilities measured by the test and later success in the program is therefore central to the meaning of the construct (Shepard, 1997), and the test users need to ensure that valid inferences are made with respect to the candidates' preparedness for TTPs and/or their placement in remedial courses based on TFLM scores. As Cronbach (1988) puts it, "the bottom line is that validators have an obligation to review whether a practice has appropriate consequences for individuals and institutions, and especially to guard against adverse consequences" (p. 6). Given this, the concept of validity adopted in this study is the unitary concept of construct validity defined by 
Messick (1989) as the procedures underlying the inferences made with respect to the meaningfulness of the test scores. Fundamental to this unitary conception of validity is that the social values and social consequences of the test use have to be taken into consideration in a discussion of validity (Messick, 1980, 1989 ) and that the validation process "must link concepts, evidence, social and personal consequences, and values" (Cronbach, 1988, p. 4).

In the field of language testing, Bachman (1990) acknowledges the significance of the value implications of test interpretation as well as the social consequences of test use for the development and use of language tests by pointing out that "tests are not developed and used in a value-free psychometric test-tube, they are virtually always intended to serve the needs of an educational system or of society at large" (p. 279). Subsequently, building on Messick's view of validity, Bachman and Palmer (1996) propose the model of test usefulness with six qualities that serve as essential bases for quality control over the entire test development process. In their model, in addition to test practicality, Bachman and Palmer identify test use consequences - which they name impact-along with reliability and construct validity, as qualities of test "use" and test "scores." To this, they add authenticity and interactiveness, the qualities of test tasks that directly contribute to the construct validity of any language test. They define authenticity as the correspondence between the test tasks and those of real-life or target language use tasks. To enhance authenticity, test tasks should resemble, as closely as possible, the TLU tasks and measure the same constructs as those of the TLU tasks. Interactiveness refers to the correspondence between the test tasks and test-takers' characteristics, such as language ability or topical knowledge. To achieve interactiveness, then, the test tasks should engage test-takers in such activities from which their language abilities can be inferred.

Bachman and Palmer (1996, p. 22), therefore, define construct validity in relation to two aspects of score interpretation: (a) the extent to which interpretations made on the basis of the test scores are indicative of the "language ability" in question, and (b) the generalizability of score interpretations to other relevant language use contexts.

Given the crucial role of test tasks for measuring language abilities in a test, Bachman and Palmer propose a detailed framework of Language Task Characteristics (2010, pp. 66-68), to be used in the process of test development, for describing the characteristics of the TLU tasks, and for comparing them with those of the test task. The present study, therefore, uses this framework as a guiding principle for analyzing the characteristics of the TLU tasks the applicants to TTPs need to perform, and compares them with those of the TFLM test.

\section{The Study: Task Analysis Procedure}

This study is part of a larger research study on the predictive validity of TFLM (Schmitt, 2015) conducted in three phases using a convergent parallel 
mixed-method design (Creswell \& Plano-Clark, 2011). In the present article, we report on the qualitative study conducted in Phase 1 of that research - that is, the analysis of the test task characteristics as well as a comparison between the test tasks and those of the three TLU domains within which the applicants to TTPs should function. The analysis of the test task characteristics was conducted using the following official documents:

- a version of TFLM;

- course descriptions and syllabi from content courses in a TTP at Université Laval;

- detailed course descriptions and syllabi for the 3 French language remedial courses (FRN-1902, FRN-1903, and FRN-1904) imposed on students based on TFLM score at the time of admission (Appendix B);

- official description of PC2 (MELS, 2001).

The above documents are either public-domain documents, accessible through Université Laval's website, or course documents published on individual course portals.

Using Bachman and Palmer's model of Task Characteristics (2010), a complete description of the characteristics of TFLM tasks and those of the 3 TLU contexts was conducted. The model of Language Knowledge, proposed by Bachman and Palmer (2010), was used to delineate the constructs involved in the input and expected response required by tasks in each TLU context. To determine the authenticity and interactiveness of the test tasks, the characteristics of the test tasks were then detailed and compared with those of the TLU contexts for possible differences and/or correspondences between them.

\section{Results}

As explained above, TFLM tasks measure test-takers' recognition ability. The test only measures grammatical knowledge out of context using a multiplechoice format. However, a survey of the documents related to the remedial courses linked to the test revealed communicative writing tasks - that is, "process-oriented writing" and "revision" - as the tasks practiced and evaluated in such courses. Similarly, the mandatory content courses and practicums required by the program necessitate such language-related academic tasks as the comprehension of oral/written material, report/summary/essay writing, and the comprehension/production of speech.

Given this, as a first step, we proceeded to the analysis of the objectives of the test tasks as compared to those common to the TLU contexts; in particular, the inferences made based on TFLM scores, the use to which those scores are put, and the impact that the test is expected to have on different players in the educational context. Table 2 reflects a detailed and, at the same time, an instant picture of the objectives of the test tasks and those of the TLU contexts. 


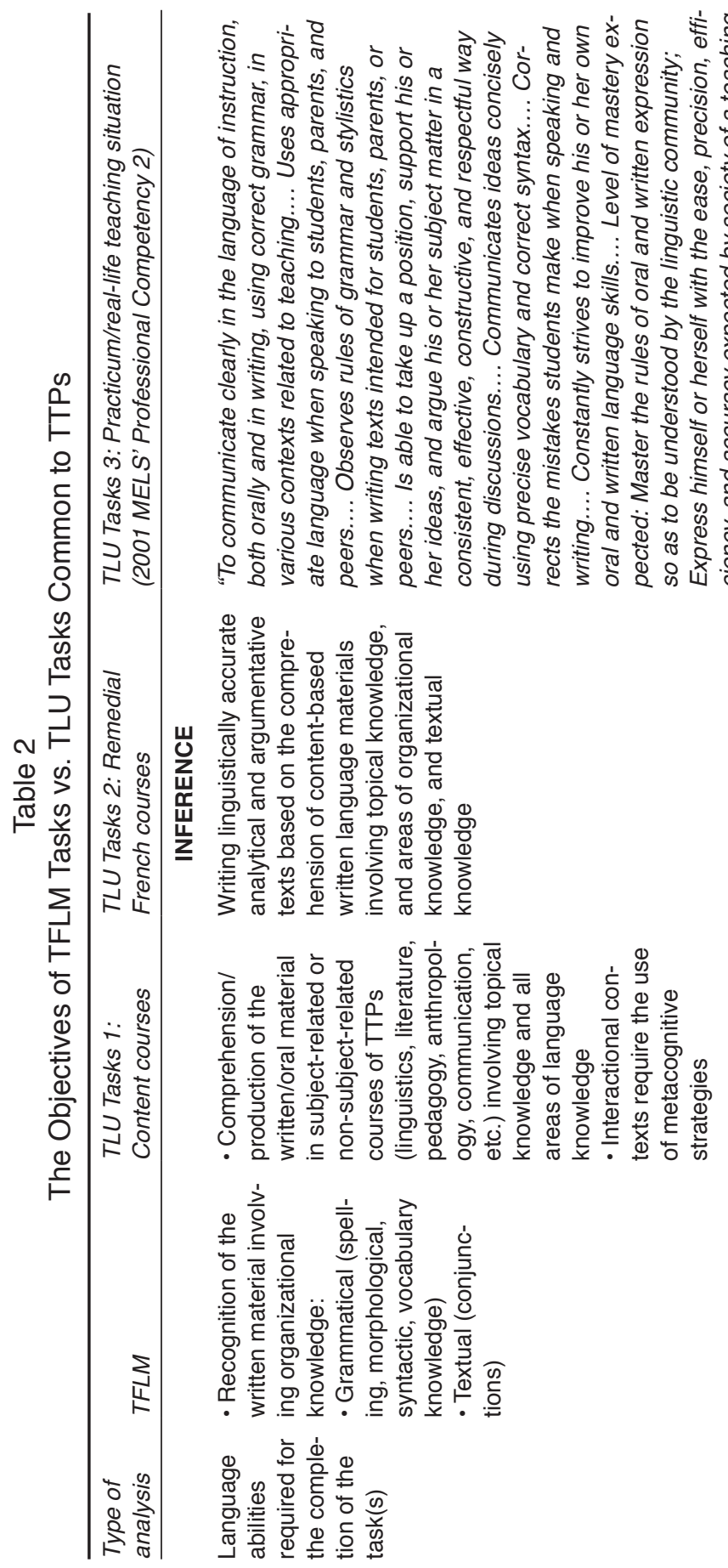

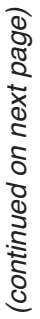

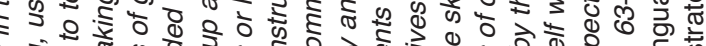

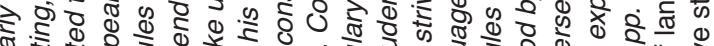
येक का

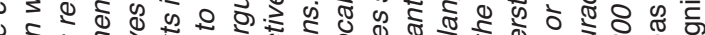

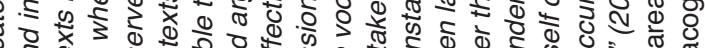
ส

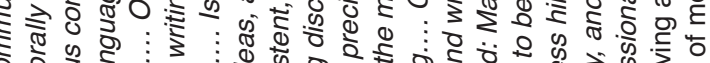
o ว

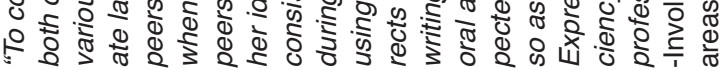

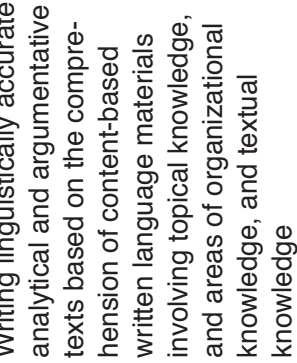

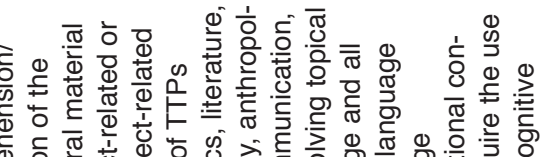

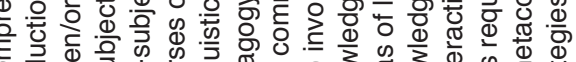

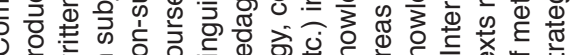

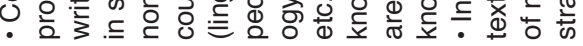

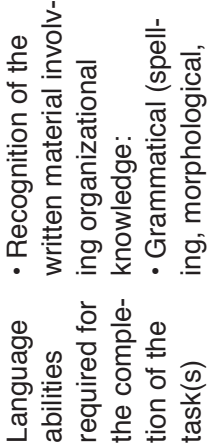




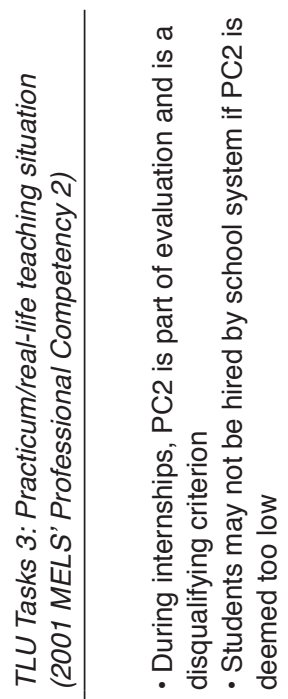

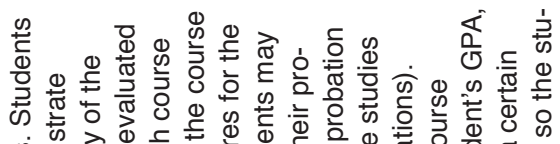

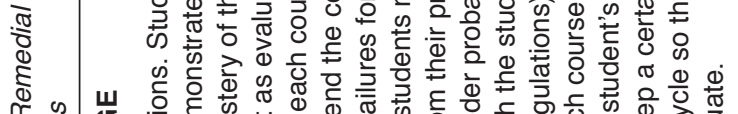
थ نे

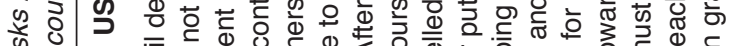

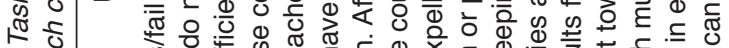

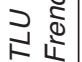
की

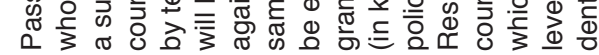

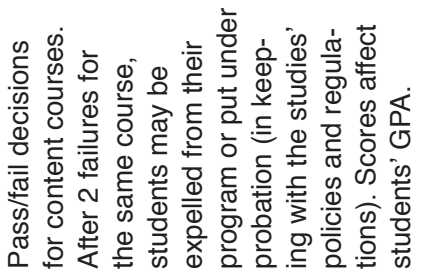

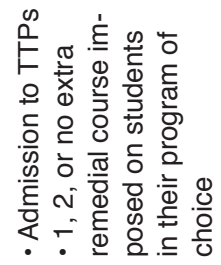

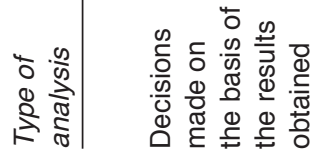

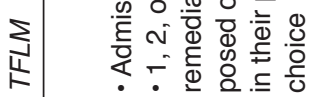

¿

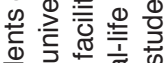

든 도원

क워요

迸

엉 항하

응 응 인

ర్ల రల

× 0 (

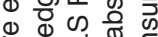

के उँ्वे ब

ת

类

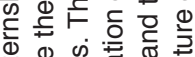

竞苋

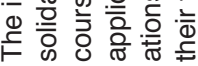

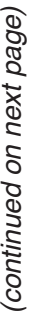

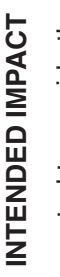

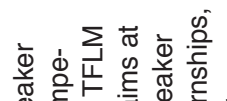

ङ

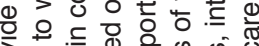

으응

흠웡

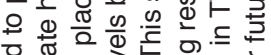

웅

卷

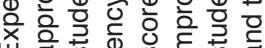

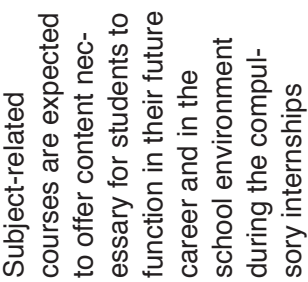

ర్d

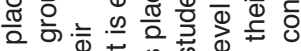

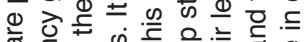

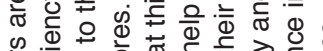

क

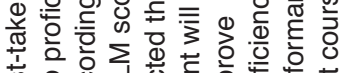

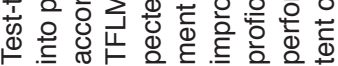

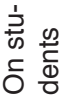




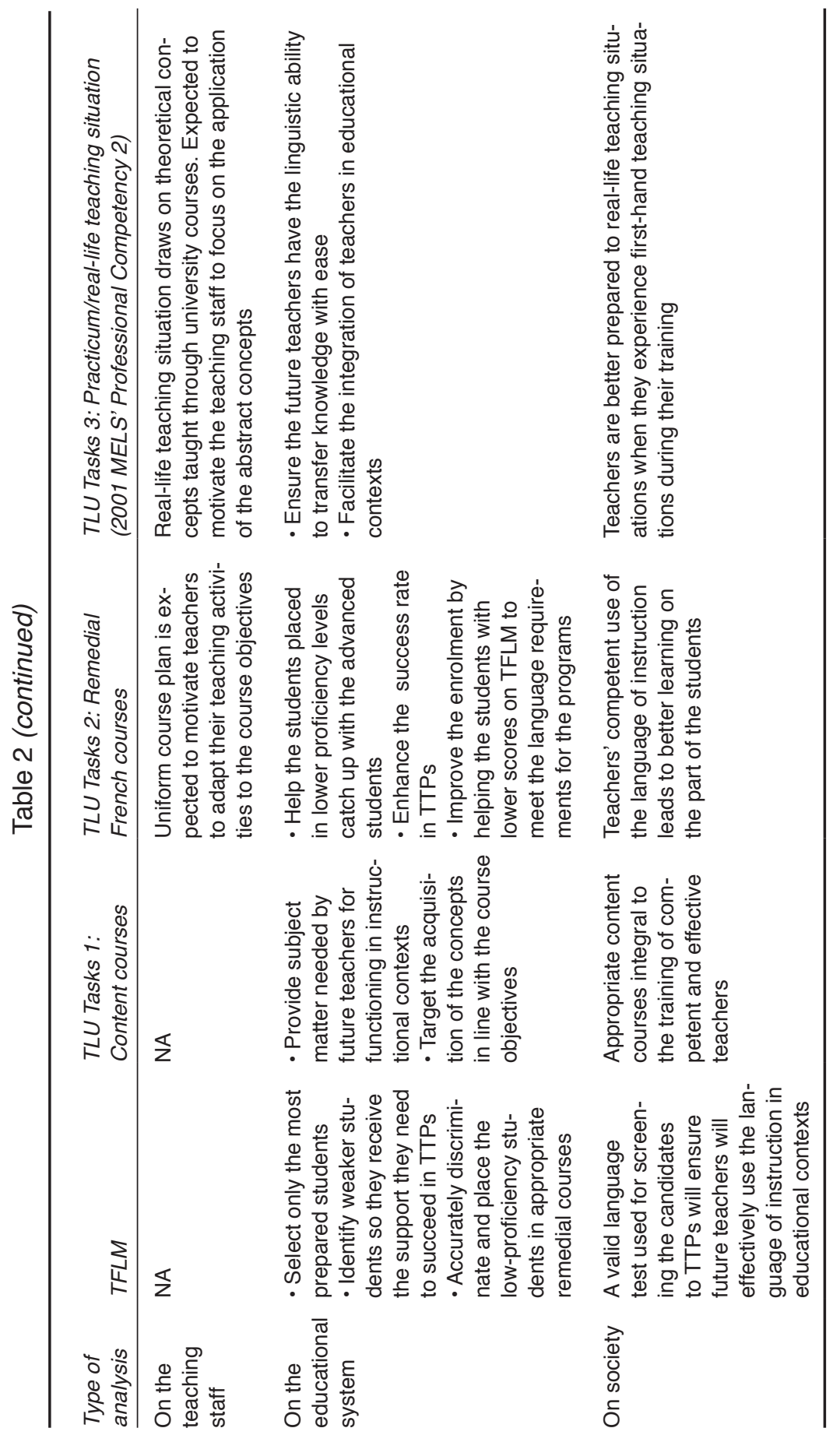


As for the areas of language knowledge required to complete the TFLM tasks and the tasks of the TLU contexts, Table 3 presents the ability areas tapped by TFLM and the tasks in the three TLU contexts.

TFLM tasks and the 3 TLU contexts' tasks were also analyzed in terms of the characteristics of the context of administration, characteristics of the administration and directives of tasks, specific characteristics of input, specific characteristics of the expected responses (output), and the relationship between content of TLU tasks and the expected output in the tasks (Table 4).

This side-by-side examination of the test tasks and those of the TLU contexts allows us to discuss whether TFLM tasks foreshadow the tasks and language needs featured in the remedial French courses, in undergraduate content courses, and in the future teaching contexts. In the next section, we will discuss whether it is logical that TFLM be used to determine the level of competency students should have in order to succeed in their program of choice. We will then draw conclusions as to the validity of TFLM as a measure of language ability and as an admission criterion for TTPs in Quebec francophone universities.

\section{Discussion}

The information presented in Tables 2, 3, and 4 reflects the characteristic features of the TFLM tasks compared to those of the three TLU tasks. This type of evidence has implications for the validity of the test tasks in general, and the extent to which the characteristics of the test tasks correspond to those of the three major TLU tasks (authenticity) and those of the intended test-takers (interactiveness) in particular.

With respect to the authenticity of TFLM tasks, the evidence suggests fundamental differences between the test tasks and those of the TLU contexts. As discussed previously, TFLM scores are used by universities to make admission and placement decisions for their programs. As such, the test scores are expected to provide a measure of the candidates' linguistic preparedness for undergraduate studies and predict their chance of success in such programs. TFLM tasks, however, as illustrated in Tables 2 and 3, measure only test-takers' knowledge of the linguistic code of French. The constructs are limited to the components of the "organizational knowledge" measured in an indirect way, out of context, and by means of a multiple choice format (RQ1). However, the tasks of the TLU contexts (content courses, remedial French courses, and real-life teaching contexts in practicums, as determined by MELS's 2001 PC2) are radically different from the indirect recognition tasks included in TFLM and the completion of them requires the mastery of a much broader range of constructs than those measured by TFLM (RQs 2, 3, 4). Content courses (TLU 1), for example, require the students to fully function in interactional and linguistically complex instructional settings (i.e., consult written materials, understand spoken language, produce written texts, and express academic concepts orally) necessitating mastery of all areas of language knowledge (Table 3) at an advanced level. 
Table 3

Language Abilities Required by TFLM Tasks vs. TLU Tasks Common to TTPs

\begin{tabular}{|c|c|c|c|c|}
\hline Type of analysis & TFLM & $\begin{array}{c}\text { TLU task 1: } \\
\text { content } \\
\text { courses }\end{array}$ & $\begin{array}{l}\text { TLU task 2: } \\
\text { Remedial } \\
\text { French } \\
\text { courses }\end{array}$ & $\begin{array}{c}\text { TLU tasks 3: practicum/ } \\
\text { real-life teaching situation } \\
\text { (2001 MELS' Professional } \\
\text { Competency 2) }\end{array}$ \\
\hline
\end{tabular}

ORGANIZATIONAL KNOWLEDGE

Grammatical knowledge

Knowledge of vo-

cabulary

Knowledge of

syntax

Knowledge of

phonology

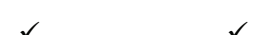

\begin{tabular}{llll} 
Knowledge of co- & & \multicolumn{2}{c}{ Textual knowledge } \\
hesion & $\checkmark$ & $\checkmark$ & $\checkmark$ \\
$\begin{array}{l}\text { Knowledge of } \\
\text { conversational }\end{array}$ & $\times$ & $\checkmark$ & $\times$
\end{tabular}

organization

\section{PRAGMATIC KNOWLEDGE}

Functional knowledge

Objectives of communication

intentions

Sociolinguistic knowledge

Knowledge of

dialects

Knowledge of reg-

isters

Knowledge of nat-

ural or idiomatic

expressions

Knowledge of cul-

tural references

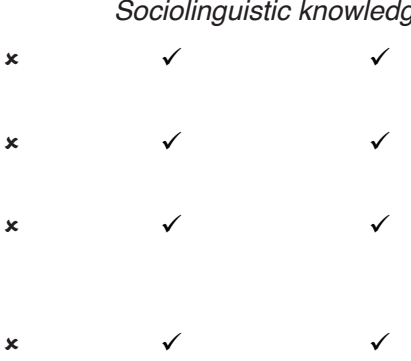

METACOGNITIVE STRATEGY USE

Areas of metacog-

nitive strategy use 


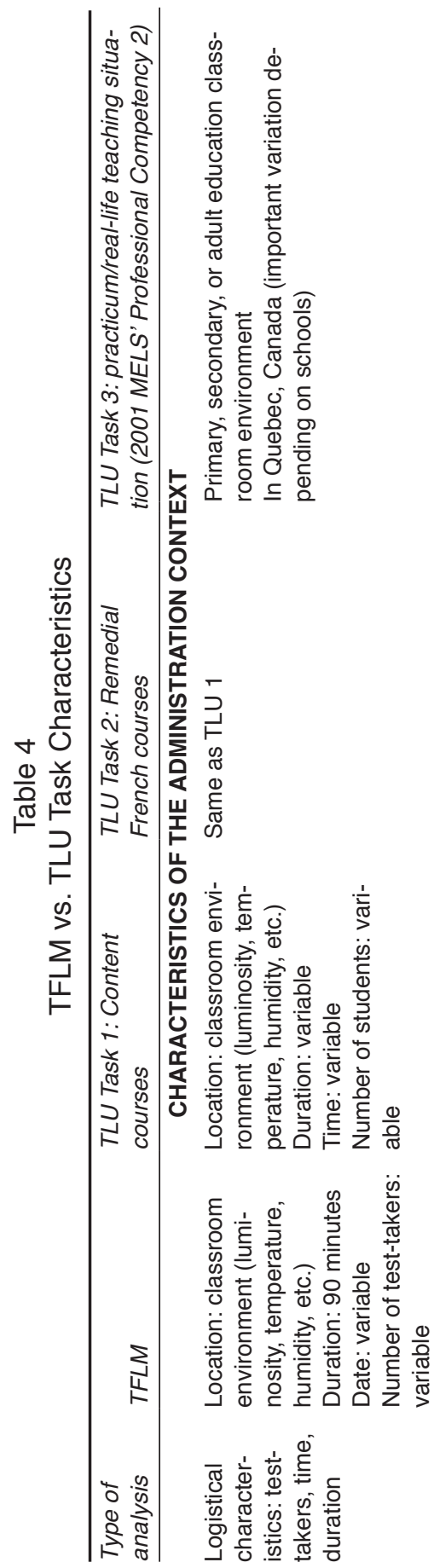

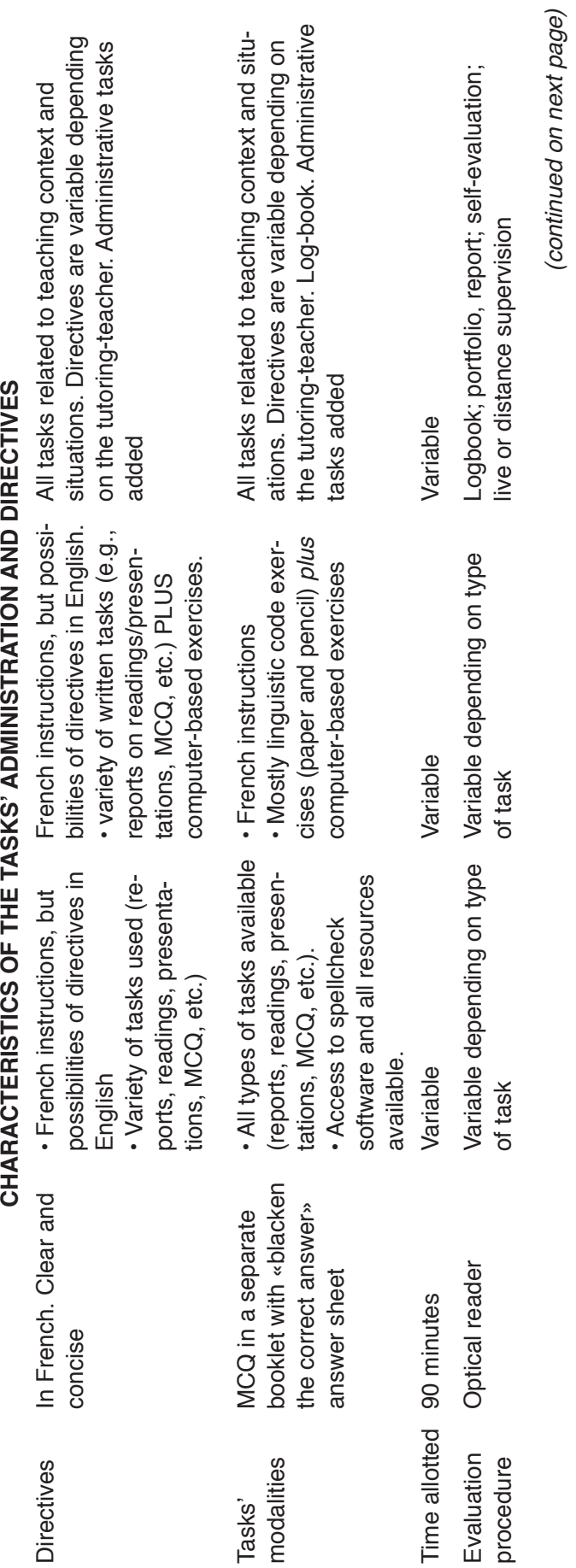

ROMAIN SCHMITT \& SHAHRZAD SAIF 


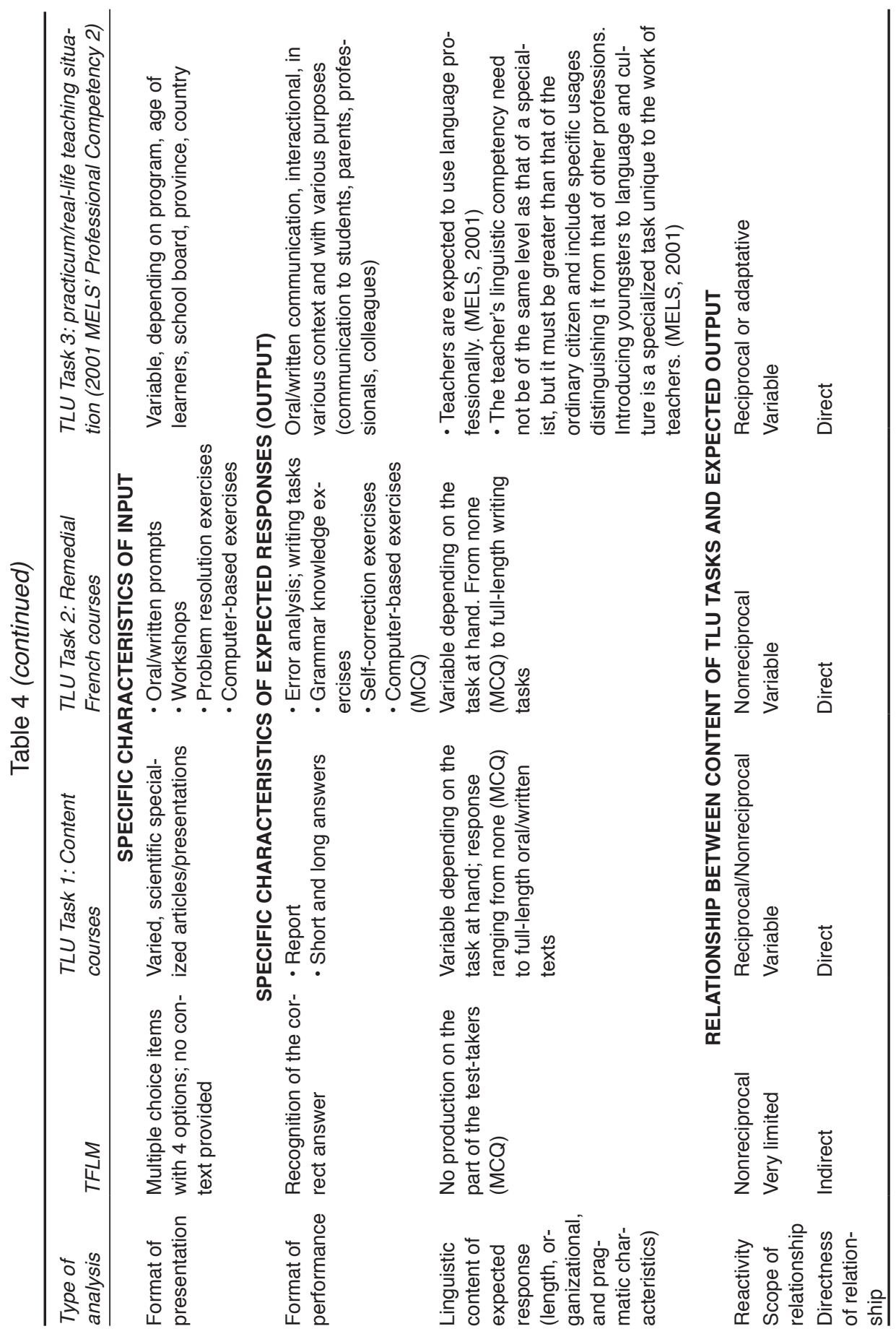


Even more paradoxical is the case of the content of the remedial French courses linked to TFLM (TLU 2) at Université Laval. Based on their TFLM score, the applicants to TTPs are placed in French language courses that are supposed to address their linguistic shortcomings as identified by TFLM. However, the tasks and constructs developed in these courses, detailed in the Results section above, are quite the opposite of those measured by TFLM (Appendix B). All three courses aim to develop the production of academic written texts based on the comprehension of written language mechanisms and using a direct communicative approach. The constructs promoted in these courses cover far beyond the organizational knowledge measured by TFLM. Note that TFLM does not include any comprehension task, reading is not evaluated, and the prompts for multiple-choice questions are extremely brief and limited. It is not clear why the students are placed in remedial language courses based on the scores from a test whose tasks and content are so different from the tasks and contents of the language courses linked to it. Similarly, TFLM tasks bear no resemblance to the complex interactional and communicative tasks required by real-life teaching contexts (TLU 3) that draw upon the topical knowledge as well as all areas of language ability. TFLM tasks, therefore, lack authenticity, as they seriously underrepresent the constructs required by TLU tasks (Messick, 1996) that teacher-training students have to perform during and after the completion of their programs.

This narrow range of language abilities measured by TFLM tasks is in sharp contrast with the range of language abilities required by the TLU tasks common to TTPs. Aside from the fact that production and comprehension abilities are not measured, the test tasks do not presuppose the appropriate area or level of topical knowledge critical to academic disciplines. In addition, the indirect nature of TFLM tasks makes it impossible to engage the test-takers in performances other than simple recognition of the grammatical forms. Test-takers are not required to process input and formulate a response through a set of interdependent tasks from which valid inferences can be made with respect to their language knowledge and strategy use, the abilities fundamental to the TLU tasks identified above. TFLM tasks, therefore, clearly lack interactiveness.

\section{Conclusion}

As discussed earlier in this article, the extent to which test tasks meet the qualities of authenticity and interactiveness has direct implications for the construct validity of the test scores and the interpretations made based on them (Bachman \& Palmer, 1996, 2010). The above findings, however, make it abundantly clear that the constructs measured by TFLM do not adequately reflect the test's purposes and that the test scores are not relevant to or appropriate for the decisions based on them. 
Given the high-stakes status of TFLM and the consequences of the decisions based on its scores for the applicants to TTPs, for the educational institutions, and for the society at large, this absence of construct validity is disconcerting. The obvious mismatch between the constructs measured by TFLM and those of the corresponding TLU contexts not only renders the intended consequences of the test score (Table 2) unachievable but is also likely to create negative consequences such as the admission of candidates who do not meet the linguistic demands of the teaching profession; wrongful placement of candidates in remedial courses; imposing unnecessary language courses, thus prolonging certain students' education while at the same time neglecting the language problem of others; loss of time, money, and energy administering a test that does not discriminate validly; and, more importantly, risking the quality of public education in Quebec by compromising the quality of the teacher education programs. The findings of this study therefore confirm that TFLM scores do not help the test users (i.e., university admission offices) to make the desired interpretations about test-takers' language abilities or make the right admission and placement decisions. An important implication of these findings for the validation of the high-stakes tests is that the decisions made on the basis of the test scores should be considered as part of the validity evidence:

A decision is a choice between courses of action. The college admits or rejects a prospective student.... Testing is intended to reduce the number of incorrect predictions and hence the number of decisions that will be regretted later. When validating a decision-making process, the concern is with the question: What is the payoff when decisions are made in the proposed way, and how does this compare with the payoff resulting when decisions are made without these data? (Cronbach, 1971, p. 448)

Given the use of TFLM scores for making high-stakes admission and placement decisions in Quebec universities, the next phase of this study (to be reported in a separate article) focuses on examining the predictive power of TFLM as evidenced by the students' scores during their four-year undergraduate studies in TTPs.

\section{The Authors}

Romain Schmitt is coordinator of the International office and internships and placement services at Cégep Limoilou, Quebec. He holds a Master's degree in applied linguistics from Université Laval with a specialization in language testing. His research interests include validity of highstakes language tests and teacher training programs.

Shahrzad Saif is a professor of Language Testing and Assessment at the Departément de langues, linguistique et traduction, Université Laval (Québec). She conducts research on the impact of high-stakes tests on teaching and learning practices, test consequences, language test development and validation, classroom assessment, and needs assessment. 


\section{References}

Association Québécoise des professeures et professeurs de Français (AQPF). (2001). Mémoire déposé pendant les États généraux de la langue française au Québec. http://www.spl.gouv. qc.ca/fileadmin/medias/pdf/memoires/220_Ass_queb_prof_fr.pdf

Bachman, L. (1990). Fundamental considerations in language testing. Oxford, UK: Oxford University Press.

Bachman, L., \& Palmer, A. (1996). Language testing in practice: Designing and developing useful language tests. Oxford, UK: Oxford University Press.

Bachman, L., \& Palmer, A. (2010). Language assessment in practice. Oxford, UK: Oxford University Press.

Blais, F. (2001). Le Canadian Achievement Test utilisé comme indicateur de réussite scolaire (Unpublished master's thesis, Université d'Alberta, Campus Saint-Jean, Edmonton).

Centre d'évaluation, Faculté des Lettres, École de langues, Université Laval. (2013). Le TFLM (Test de Français Laval-Montréal), Épreuve de français langue maternelle. Retrieved from http:// www.elul.ulaval.ca/fileadmin/elul/fichiers/tests-de-classement/sinscrire-a-un-test/TFLM_ Description.pdf

Commission des états généraux sur l'éducation. (1996). Exposé de la situation. Gouvernement du Québec, Ministère de l'éducation.

Commission des états généraux sur l'avenir de la langue française au Québec. (2011). Le française, une langue pour tout le monde (Rapport Larose). Quebec, QC: Gouvernement du Québec, Ministère de l'éducation.

Creswell, J. W., \& Plano Clark, V. L. (2011). Designing and conducting mixed methods research (2nd ed.). Los Angeles, CA: Sage.

Cronbach, L. J. (1971). Validity. In R. L. Thorndike (Ed.), Educational measurement (pp. 443-507). Washington, DC: American Council on Education.

Cronbach, L. J. (1988). Five perspectives on validation argument. In H. Wainer \& H. Braun (Eds.), Test validity (pp. 3-17). Hillside, NJ: Erlbaum.

Elder, C. (1993). Language proficiency as a predictor of performance in teacher education. Melbourne Papers in Language Testing, 2(1), 68-85.

Gagnon, K. (2005, November 28). À l'école des cancres. La Presse. Montréal.

Gauvreau, C. (2003). Renforcer la maîtrise du français : une priorité! Actualités UQAM, 3(7), 3.

Messick, S. (1980). Test validity and the ethics of assessment. American Psychologist, 35(11), 10121027.

Messick, S. (1989). Validity. In R. L. Linn (Ed.), Educational measurement (pp. 13-103). New York: Macmillan.

Messick, S. (1996). Validity and washback in language testing. Language Testing, 13(3), 241-256.

Ministère de l'éducation, du Loisir et du Sport (MELS). (2001). Teacher training: orientations and professional competencies. Retrieved from http://www.education.gouv.qc.ca/fileadmin/site_ web/documents/dpse/formation_ens_a.pdf

Morris, L., \& Cobb, T. (2004). Vocabulary profiles as predictors of the academic performance of teaching English as a second language trainees. System, 32(1), 75-87.

Romainville, M. (1997). Peut-on prédire la réussite d'une première année universitaire? Revue Française de Pédagogie, 119, 81-90.

Schmitt, R. (2015). Analyse de la validité prédictive d'une épreuve standardisée de langue française chez des étudiants locuteurs natifs francophones inscrits dans des programmes de formation en enseignement : le cas du TFLM (Unpublished master's thesis, Université Laval, Québec, Québec).

Shepard, L. A. (1997). The centrality of test use and consequences for test validity. Educational Measurement: Issues and Practice, 16(2), 5-8, 13, 24. 


\section{Appendix A. TFLM Descriptive Document Sent to Candidates, Université Laval, Fall 2013 (Centre d'évaluation, Faculté des Lettres, 2013)}

Centre d'évaluation

École de langues de l'université Laval

\section{TFLM (Test de français Laval-Montréal), épreuve de français langue maternelle}

Le TFLM est un test objectif de 65 questions à choix multiple. Il a été conçu par I'Université de Montréal et I'Université Laval et ses six versions ont fait l'objet d'une rigoureuse validation scientifique.

Pour s'y préparer, vous pouvez consulter le manuel suivant : CLAMAGERAN S., I. CLERC, M. GRENIER et R.-L. ROY. 2015, Le français apprivoisé, $4^{e}$ édition, Montréal, Modulo.

\section{Description}

\section{L'orthographe lexicale (4 questions)}

L'orthographe grammaticale ( 24 questions) :

- Homonymes

- Accords de l'adjectif, des indéfinis, du verbe, du participe passé

La morphologie (5 questions) :

- Le genre et le pluriel de certains noms

- La conjugaison

La syntaxe (13 questions):

- Emploi des auxiliaires, des modes et des temps

- Emploi du pronom relatif et de la conjonction de subordination

- Structure de la phrase, négation, interrogation

- Ponctuation

Le vocabulaire (19 questions) :

- Anglicismes

- Mots-liens

- Emploi de la préposition

- Connaissance du vocabulaire

Temps alloué : 90 minutes.

Aucun ouvrage de référence n'est permis. 


\section{Appendix B. Course Plans for FRN-1902, FRN-1903, and FRN-1904, Université Laval, Fall 2013}

UNIVERSITÉ LAVAL

Faculth des lettres

\section{FRN-1902 : Français écrit pour la formation à l'enseignement I NRC 16884}

Hiver 2013

Mode d'enseignement : Présentiel

Temps consacré : 3-0-6

Crédit(s) : 3

Composantes de la langue écrite et des textes écrits, analyse grammaticale, profil du scripteur compétent, processus rédactionnel, relecture et autocorrection. Remarque: Ce cours, non contributoire, est réservé aux étudiants des programmes de formation à l'enseignement qui ont obtenu une note inférieure à $60 \%$ au TFLM.

Plage horaire :

Cours en classe

Mercredi $18 \mathrm{~h} 30$ à $21 \mathrm{~h} 20$ DES-0126 Du 21 janv. 2013 au 30 avr. 2013

Il se peut que l'horaire du cours ait été modifié depuis la dernière synchronisation avec Capsule. Vérifier l'horaire dans Capsule

Site de cours :

https://www.portaildescours.ulaval.ca/ena/site/accueil?idSite $=45708$

\section{Description du cours}

\section{Introduction}

Le cours FRN-1902 Français écrit pour la formation à l'enseignement I met l'accent sur la responsabilisation de chaque étudiant, qui doit avoir pour but de développer sa compétence dans l'utilisation des diverses composantes de la langue écrite et des textes écrits (analyse grammaticale, profil du scripteur compétent, processus rédactionnel, relecture et autocorrection) et d'accroitre son autonomie dans la résolution des difficultés qu'il éprouve. Ce cours s'inscrit dans le cadre général de la formation des maitres et prend en considération le rôle de modèle linguistique que l'enseignant est appelé à jouer auprès de ses élèves. On s'attend donc à beaucoup de rigueur et de sérieux de la part de chaque étudiant, premier responsable de son apprentissage.

\section{Modalités particulières de l'offre de cours}

Ce cours est offert en salle sur une période de 14 semaines.

Temps consacré au cours : cours de trois heures par semaine et de 6 heures de travail personnel hors classe en moyenne.

\section{Objectifs généraux}

Avec l'attitude intellectuelle qui convient à l'étude de la langue au niveau universitaire et en considérant l'écriture comme un moyen d'enrichir sa pensée et de développer sa capacité d'expression, l'étudiant devra :

1. Maitriser les dimensions linguistique, textuelle et discursive de la communication écrite et leurs particularités liées au domaine de l'enseignement.

2. Maitriser le processus rédactionnel, plus particulièrement les stratégies permettant de rédiger un texte clair et cohérent.

3. Connaitre les principales composantes de la grammaire du texte et de la grammaire de la phrase.

4. Avoir conscience du caractère systémique de la grammaire française. 


\title{
A. Objectifs spécifiques relatifs à la communication écrite et à la rédaction
}

En tenant compte des liens entre la compétence langagière et les habiletés intellectuelles liées aux activités d'apprentissage, l'étudiant devra :

1. Rédiger des textes à dominante analytique et argumentative sur des sujets liés à l'éducation en tenant compte de la situation de communication et en respectant le fonctionnement de la langue et des discours.

2. Analyser une problématique et rédiger son point de vue de manière pertinente.

3. Évaluer les forces et les faiblesses de ses productions écrites sur les plans linguistique, textuel et discursif, et y apporter les corrections requises en les justifiant en fonction des critères travaillés en classe.

\section{B. Objectifs spécifiques relatifs à la connaissance du français}

1. Reconnaitre, en contexte, la classe des mots et les principales fonctions syntaxiques, de même que les différentes structures syntaxiques.

2. Distinguer les différentes composantes de la langue écrite (grammaire du texte, syntaxe, ponctuation, orthographe, etc.) afin de pouvoir identifier le type d'erreurs dans ses textes.

3. Utiliser efficacement les principaux ouvrages de référence sur la langue.

4. Connaitre les principales différences entre la langue écrite et la langue orale normée.

\section{FRN-1903 : Français écrit pour la formation à} l'enseignement II

Faculti des lattres NRC 13880

Hiver 2013

\author{
Mode d'enseignement : Présentie \\ Temps consacré : 3-0-6 \\ Crédit(s) : 3 \\ Préalables : FRN 1902
}

Composantes de la langue écrite et des textes écrits, analyse grammaticale, profil du scripteur compétent, processus rédactionnel, relecture et autocorrection. Remarque : Ce cours est réservé aux étudiants des programmes de formation à l'enseignement qui, ayant obtenu au moment de leur admission au programme une note inférieure à $60 \%$ au TFLM, ont, depuis, réussi le cours FRN-1902.

Plage horaire :

Cours en classe

Mercredi 15 h30 à 18 h20 DKN-3110 Du 21 janv. 2013 au 30 avr. 2013

Il se peut que l'horaire du cours ait été modifié depuis la dernière synchronisation avec Capsule. Vérifier l'horaire dans Capsule

Site de cours :

https://www.portaildescours.ulaval.ca/ena/site/accueil?idSite $=44810$ 


\section{Description du cours}

\section{Introduction}

Ce cours s'adresse aux étudiants des programmes de formation à l'enseignement qui, ayant obtenu au moment de leur admission au programme une note inférieure à $60 \%$ au TFLM, ont, depuis, réussi le cours FRN-1902. Contenu : composantes de la langue écrite et des textes écrits, analyse grammaticale, profil du scripteur compétent, processus rédactionnel, relecture et autocorrection.

\section{Modalités particulières de l'offre de cours}

Ce cours est offert en salle sur une période de 14 semaines.

Temps consacré au cours : cours de trois heures par semaine et de six heures de travail personnel hors classe en moyenne.

\section{Objectifs généraux}

Avec l'attitude intellectuelle qui convient à l'étude de la langue au niveau universitaire et en considérant l'écriture comme un moyen d'enrichir sa pensée et de développer sa capacité d'expression, l'étudiant devra :

1. Maitriser les dimensions linguistique, textuelle et discursive de la communication écrite et leurs particularités liées au domaine de l'enseignement.

2. Maitriser le processus rédactionnel, plus particulièrement les stratégies permettant de rédiger un texte clair et cohérent.

3. Connaitre les principales composantes de la grammaire du texte et de la grammaire de la phrase.

4. Avoir conscience du caractère systémique de la grammaire française.

\section{Objectifs particuliers}

\section{A. Objectifs spécifiques relatifs à la communication écrite et à la rédaction}

En tenant compte des liens entre la compétence langagière et les habiletés intellectuelles liées aux activités d'apprentissage, l'étudiant devra :

1. Rédiger un texte à dominante analytique et argumentative sur un sujet lié à l'éducation en tenant compte de la situation de communication et en respectant le fonctionnement de la langue et des discours.

2. Évaluer les forces et les faiblesses de ses productions écrites sur les plans linguistique, textuel et discursif, et $\mathrm{y}$ apporter les corrections requises en les justifiant en fonction des critères travaillés en classe.

\section{B. Objectifs spécifiques relatifs à la connaissance du français}

1. Reconnaitre, en contexte, la classe des mots et les principales fonctions syntaxiques, de même que les différentes structures syntaxiques.

2. Distinguer les différentes composantes de la langue écrite (grammaire du texte, syntaxe, ponctuation, orthographe, etc.) afin de pouvoir identifier le type d'erreurs dans ses textes.

3. Utiliser efficacement les principaux ouvrages de référence sur la langue.

4. Connaitre les principales différences entre la langue écrite et la langue orale normée.

\section{Éléments de contenu}

\section{Éléments de contenu relatifs à la communication écrite et à la rédaction}

1. Introduction à la notion de « texte " : dimension linguistique, dimension textuelle et dimension discursive. 
2. Communication orale et communication écrite. La communication écrite à l'université et dans le milieu scolaire.

3. Thème et propos: deux moteurs de la construction du texte.

4. Profil du scripteur compétent de niveau universitaire.

5. Stratégies d'écriture efficace (besoins et attentes d'ordre communicationnel).

6. Relations langage/pensée.

7. Modalités de discours : description, narration, explication, argumentation, compte-rendu critique.

8. Éléments d'analyse textuelle : fonctions et caractéristiques distinctives des textes à dominante analytique et à dominante argumentative.

9. Le processus rédactionnel : de l'intention d'écriture (ou du mandat d'écriture) jusqu'au texte final ; la question de la méthode (planification, rédaction, révision).

10. La situation de communication : définition(s), composition ; caractéristiques de la situation de communication propre à la relation pédagogique ou au milieu scolaire.

11. La * question * comme mandat d'écriture : comment analyser et exploiter une question lors de la production d'un texte argumentatif.

12. Stratégies d'autoévaluation et d'autocorrection : relecture(s), révision(s), correction et réécriture. Justification des diverses interventions visant à améliorer un texte. La réécriture comme moyen de développer les habiletés scripturales.

13. Consultation des ouvrages de référence et utilisation des aides informatiques à la rédaction.

\section{Éléments de contenu relatifs à la consolidation de la connaissance du français}

1. La phrase complexe et la liaison des phrases.

2. Les indéfinis.

3. La ponctuation.

4. Questions de syntaxe : I'interrogation, la négation, l'emploi des pronoms et des déterminants possessifs, des pronoms relatifs, de la préposition, du subjonctif et erreurs courantes.

5. Cas particuliers d'accord dans le GV.

6. Vocabulaire : variation sociale, emploi du mot juste et écarts lexicaux.

7. Cohérence textuelle.

\section{Approche pédagogique}

Les activités d'enseignement et d'apprentissage apprentissage sont variées : brefs exposés théoriques, exercices individuels ou en équipe (en classe ou hors classe). Elles sont pour chaque étudiant autant d'occasions de prendre conscience de ses forces et de ses faiblesses en ce qui concerne la connaissance de la langue ou l'habileté à rédiger, et d'identifier, avec l'aide du professeur, les moyens de combler les lacunes observées.

\section{Modalités d'encadrement}

Pour prendre rendez-vous avec moi, faites-moi parvenir un courriel dans lequel vous m'indiquerez à quels moments vous êtes disponible pour venir me rencontrer. Je vous répondrai dans les meilleurs délais.

\section{Appréciation de l'enseignement}

En conformité avec la Politique de valorisation de l'enseiqnement et Dispositions relatives à l'évaluation de l'enseiqnement à /'Université Laval, il est possible que le cours que vous suivez soit évalué. Si tel est le cas, vous recevrez une invitation à remplir un questionnaire d'appréciation. Votre opinion est très importante, car elle permettra d'améliorer la qualité de ce cours. Nous comptons donc grandement sur votre collaboration.

\section{Appréciation de l'enseignement}

En conformité avec la Politique de valorisation de l'enseignement et Dispositions relatives à l'évaluation de l'enseignement à l'Université Laval, il est possible que le cours que vous suivez soit évalué. Si tel est le cas, vous recevrez une invitation à remplir un questionnaire d'appréciation. Votre opinion est très importante, car elle permettra d'améliorer la qualité de ce cours. Nous comptons donc grandement sur votre collaboration. 


\section{FRN-1904 : Français écrit pour la formation à l'enseignement III}

Faculti des lattres

NRC 13912

Hiver 2013

Mode d'enseignement : Présentiel

Temps consacré : $3-0-6$

Crédit(s) : 3

Préalables : Examen Test de français avec résultat de 060.0 à 100.0

Composantes de la langue écrite et des textes écrits, analyse grammaticale, profil du scripteur compétent, processus rédactionnel, relecture et autocorrection. Remarque : Ce cours est réservé aux étudiants des programmes de formation à l'enseignement qui ont obtenu une note située entre 60 et $75 \%$ au TFLM.

Plage horaire :

Cours en classe

Jeudi 15 h30 à 18 h20 DKN-3E Du 21 janv. 2013 au 30 avr. 2013

Il se peut que l'horaire du cours ait été modifié depuis la dernière synchronisation avec Capsule. Vérifier l'horaire dans Capsule

Site de cours :

https://www.portaildescours,ulaval.ca/ena/site/accueil?idSite $=45216$

\section{Description du cours}

\section{Introduction}

Le cours Français écrit pour la formation à l'enseignement III met l'accent sur la responsabilisation de chaque étudiant, qui doit avoir pour but de développer sa compétence dans l'utilisation des diverses composantes de la langue écrite et des textes écrits (analyse grammaticale, profil du scripteur compétent, processus rédactionnel, relecture et autocorrection) et d'accroitre son autonomie dans la résolution des difficultés qu'il éprouve. Ce cours s'inscrit dans le cadre général de la formation des maitres et prend en considération le rôle de modèle linguistique que l'enseignant est appelé à jouer auprès de ses élèves. On s'attend donc à beaucoup de rigueur et de sérieux de chaque étudiant, premier responsable de son apprentissage.

* Dans ce cours, on recommande l'application des rectifications orthographiques.

\section{Modalités particulières de l'offre de cours}

Ce cours est offert en salle sur une période de 15 semaines.

Temps consacré au cours : cours de trois heures par semaine et de 6 heures de travail personnel hors classe en moyenne.

\section{Objectifs qénéraux}

Avec l'attitude intellectuelle qui convient à l'étude de la langue au niveau universitaire et en considérant l'écriture comme un moyen d'enrichir sa pensée et de développer sa capacité d'expression, l'étudiant devra :

1. Maitriser les dimensions linguistique, textuelle et discursive de la communication écrite et leurs particularités liées au domaine de l'enseignement.

2. Maitriser le processus rédactionnel, plus particulièrement les stratégies permettant de rédiger un texte clair et cohérent.

3. Connaitre les principales composantes de la grammaire du texte et de la grammaire de la phrase.

4. Avoir conscience du caractère systémique de la grammaire française. 


\section{A. Objectifs spécifiques relatifs à la communication écrite et à la rédaction}

En tenant compte des liens entre la compétence langagière et les habiletés intellectuelles liées aux activités d'apprentissage, l'étudiant devra :

1. Rédiger un texte à dominante analytique et argumentative sur un sujet lié à l'éducation en tenant compte de la situation de communication et en respectant le fonctionnement de la langue et des discours.

2. Analyser une problématique et rédiger son point de vue de manière pertinente.

3. Évaluer les forces et les faiblesses de ses productions écrites sur les plans linguistique, textuel et discursif, et $\mathrm{y}$ apporter les corrections requises en les justifiant en fonction des critères travaillés en classe.

\section{B. Objectifs spécifiques relatifs à la connaissance du français}

1. Reconnaitre, en contexte, la classe des mots et les principales fonctions syntaxiques, de même que les différentes structures syntaxiques.

2. Distinguer les différentes composantes de la langue écrite (grammaire du texte, syntaxe, ponctuation, orthographe, etc.) afin de pouvoir identifier le type d'erreurs dans ses textes.

3. Utiliser efficacement les principaux ouvrages de référence sur la langue.

4. Connaitre les principales différences entre la langue écrite et la langue orale normée.

\section{Éléments de contenu}

\section{A. Éléments de contenu relatifs à la communication écrite et à la rédaction}

1. Introduction à la notion de « texte $»$ : dimension linguistique, dimension textuelle et dimension discursive.

2. Communication orale et communication écrite. - La communication écrite à l'université et dans le milieu scolaire.

3. Thème et propos : deux moteurs de la construction du texte. - Profil du scripteur compétent de niveau universitaire.

4. Stratégies d'écriture efficace (besoins et attentes d'ordre communicationnel). - Relations langage/pensée.

5. Modalités de discours : description, narration, explication, argumen-tation.

6. Éléments d'analyse textuelle : fonctions et caractéristiques distinctives des textes à dominante analytique et à dominante argumentative.

7. Le processus rédactionnel : de l'intention d'écriture (ou du mandat d'écriture) jusqu'au texte final ; la question de la méthode (planification, rédaction, révision).

8. La situation de communication : définition(s), composition ; caractéristiques de la situation de communication propre à la relation pédagogique ou au milieu scolaire.

9. La \& question * comme mandat d'écriture : comment analyser et exploiter une question lors de la production d'un texte argumentatif.

10. Stratégies d'autoévaluation et d'autocorrection : relecture(s), révision(s), correction et réécriture. Justification des diverses interventions visant à améliorer un texte. La réécriture comme moyen de développer les habiletés scripturales.

11. Consultation des ouvrages de référence et utilisation des aides informatiques à la rédaction.

\section{B. Éléments de contenu relatifs à la consolidation de la connaissance du français}

1. Deux concepts clés : grammaire de la phrase et grammaire du texte.

2. La phrase et la construction des groupes de mots.

3. Les dictionnaires.

4. Révision des règles générales d'accord dans le GN et le GV.

5. Accords : règles et cas particuliers dans le GN et le GV.

6. Orthographe lexicale : rectifications orthographiques.

7. Vocabulaire : la variation sociale, I'emploi du mot juste et les écarts lexicaux.

8. Éléments de ponctuation : problèmes fréquents.

9. Questions de syntaxe.

10. Cohérence textuelle : problèmes fréquents.

\section{Approche pédagogique}

Les activités d'enseignement et d'apprentissage sont variées : brefs exposés théoriques, exercices individuels ou en équipe (en classe ou hors classe). Elles sont pour chaque étudiant autant d'occasions de prendre conscience de ses forces et de ses faiblesses en ce qui concerne la connaissance de la langue ou l'habileté à rédiger, et d'identifier, avec l'aide du professeur, les moyens de combler les lacunes observées. 
Même si plusieurs aspects de ce cours nécessitent un accès à Internet, il ne s'agit pas d'un cours en ligne. Vous devez donc être présent en classe si vous voulez bénéficier de ce qui y est enseigné. Si vous devez vous absenter, il est de votre responsabilité de vous informer auprès des autres étudiants et de consulter le portail pour vous tenir à jour. En aucun cas je ne reprendrai la totalité de la matière d'un cours en privé. Il me fera toutefois plaisir de répondre à vos questions pour préciser certaines notions, en personne ou par courrier électronique.

Seule une absence due à un événement indépendant de votre volonté (accident de la route, maladie grave, décès) et appuyée par une preuve matérielle (billet du médecin daté, etc.) permet à l'étudiant de reprendre un examen manqué ou de reporter la date de remise d'un travail. Toute autre raison (rendez-vous chez le dentiste, réveil-matin brisé, soirée difficile, etc.) ne sera pas prise en compte et l'étudiant se verra attribuer le note de zéro pour l'évaluation manquée. 